\title{
Bacterial Bioagents and Compost as Two Tools for Management of Eggplant Fusarium Wilt
}

\author{
Khairy Abdel-Maksoud Abada ${ }^{1}$ *, Amany Mohamed Farouk Attia ${ }^{1}$, \\ Ibrahim Abdel-Moneim El-Fiki ${ }^{2}$ \\ ${ }^{1}$ Plant Pathol Department, Faculty Agriculture, Cairo Unniversity, Giza, Egypt \\ ${ }^{2}$ Plant Pathol Department, Faculty Agriculture at Moshtohor, Benha Unniversity, Toukh, Egypt
}

Email address:

dr_khairy_abada@yahoo.com (K. Abdel-Maksoud A.)

${ }^{*}$ Corresponding author

\section{To cite this article:}

Khairy Abdel-Maksoud Abada, Amany Mohamed Farouk Attia, Ibrahim Abdel-Moneim El-Fiki. Bacterial Bioagents and Compost as Two Tools for Management of Eggplant Fusarium Wilt. Frontiers in Environmental Microbiology. Vol. 4, No. 1, 2018, pp. 1-10. doi: $10.11648 /$ j.fem.20180401.11

Received: December 20, 2017; Accepted: January 16, 2018; Published: February 2, 2018

\begin{abstract}
Isolation trials from the roots of wilted eggplant plants grown at five governorates yielded many fungal isolates. The isolates of the fungus $F$. oxysporum were selected to test their pathogenicity and Kalubia isolate was the most virulent one. The fungus was virulent to eggplant and no apparent infection was found in case of the other seven tested plants. Therefore, the fungus F. oxysporum named Fusarium oxysporum Schlecht. f. sp. melongenae Fomg. All the tested bioagents and compost tea caused significant reduction to the linear growth of F.o.f.sp. melongenae and the germinated conidiospores compared with control treatment. Adding the two tested bioagents, i.e. B. subtilis and P. fluorescens each alone or in combination to the infested soil with the causal pathogen resulted in significant reduction to eggplant wilt with significant increase to plant height as well as the number of fruits and their weight / plant compared with control treatment. Moreover, amending the soil with compost increased the efficiency of the two bioagents in reducing the disease and increasing the produced fruit yield compared with the clay soil only. In addition, the fungicide Topsin M-70 was the superior treatment in reducing the severity of the disease and increasing plant height and the produced fruit yield followed by the combination of $B$. subtilis and P. fluorescens. The total phenol compounds were greatly increased in the bacterial treated plants and compost as compared to the control (untreated plants with the bioagents) and those infested with the pathogen only.
\end{abstract}

Keywords: Bacterial Bioagents, Compost, Eggplant, Fusarium Wilt, Disease Management, Fruit Yield, Total Phenol Compounds

\section{Introduction}

Eggplant (Solanum melongenae L.) is considered one of the most important vegetable crops in Egypt for local consumption and exportation. It is a preferable food for poor and rich people. Therefore, improving the bioproduction of this crop is one of the objectives in agriculture in many countries.

The total cultivated area with eggplant in Egypt is unknown exactly, which estimated by about 74.125 feddan during 2016 growing season with a total production of about 466723 ton at the rate of 6.3 ton / feddan.

Eggplant is liable to be attack by many bacterial, fungal, viral and nematode diseases as well as physiological disorder. However, Fusarium wilt is considered the major devastative and destructive disease affecting crop production of eggplant [5], [6], [22], [26].

Due to the cultivated area in Egypt is limited, therefore crop rotation is not applied and this caused great difficulties, especially in case of specific soil-borne pathogens such as eggplant Fusarium wilt. On the other hand, the use of chemical management against such diseases mostly gives good results. However, improper use of fungicides leads mostly to environmental pollution, disasters throughout the world and the phenomena of resistance to the plant pathogens [9]. Therefore, to overcome these difficulties, it is urgent to apply biological control as an alternative safe efficient 
method against such diseases, which biological control is considered an important approach of agricultural biotechnology in recent years for controlling many soil-borne plant pathogens [1], [2], [3], [24], [40].

The fungus Fusarium wilt of eggplant (Fusarium oxysporum Schlecht. f. sp. melongenae Fomg) is one of the major fungal diseases causing economical yield losses in Egypt as well as several other eggplant producing countries. Under optimal infection conditions, such as temperature, high soil moisture level, soil compaction and poor soil drainage, this pathogen can completely destroy the grown plants. Infected plants exhibit leaf chlorosis and slight vein clearing on outer leaflets, followed by yellowing and dropping of leaves, then xylem browning of the stem and finally death of the aboveground parts. The infection and the symptoms are observed when the temperature is about $25^{\circ} \mathrm{C}$. Fusarium wilt spreads widely, especially on eggplant plantations in Eastern Mediterranean Region, which causes serious yield losses [5], [22].

Management of plant disease is supposed to be a dynamic and multifactorial process. Hence, it is assumed that plant defense response can be activated by specific recognition of some microorganisms by the plant [18]. There may be whole organisms or products secreted by microorganisms under the influence of which plants initiate defense response [3], [7]

This work was performed to investigate the potential of some Bacillus spp., i.e. Bacillus chitinosporus, $B$. megaterium, B. pumilus, B. subtilis and B. thuringiensis as well as Pseudomonas fluorescens and P. putida in addition to compost tea on the growth and germination of the conidiospores of F.o.f.sp. melongenae. Also, the efficacy of both $B$. subtilis and $P$. fluorescens in combination with compost on management of eggplant Fusarium wilt and the formation of phenol compounds in eggplant plants.

\section{Materials and Methods}

\subsection{Isolation, Purification and Identification of the Associated Fungi to Eggplant Wilt}

Eggplant plants (Balady white cv.) showing characteristic symptoms of wilt were collected from Dakahlia, Menofia, Kalubia, Giza and Fayoum governorates. The infected root samples were thoroughly washed in running tap water and cut into small pieces with lesion having half healthy and half diseased tissue. The pieces were surface sterilized with $2 \%$ sodium hypochlorite for two minutes. The tissue pieces were subsequently washed in three changes of sterile water to eliminate excess sodium hypochlorite and then the pieces were transferred onto PDA medium in Petri-dishes. Plates were incubated at $25 \pm 2{ }^{\circ} \mathrm{C}$ and observed periodically for growth of the fungi. The pure cultures of the isolated fungi were obtained by hyphal tip method and/ or single spore technique and maintained on PDA slants throughout the investigation. The emerged fungi were identified on the basis of cultural, morphological characteristics and the description of [10], [13].

\subsection{Pathogenicity Test of the Fusarium oxysporum Isolates and Identification of the Forma Specials}

The inoculum of $F$. oxysporum was prepared by culturing the fungus on potato dextrose agar (PDA) medium for 7 days in Petri-plates. Conidial suspension was prepared by pouring $20 \mathrm{ml}$ of sterile distilled water in each Petri-plate. The concentration of the conidia was adjusted to $1 \times 10^{3}$ conidia per milliliter using haemocytometer.

Three transplants (Balady white cv.) of 30 day-old, grown in foam trays contained disinfested soil (peat moss + clay+ sand +vermiculite), were transplanted in each plastic pot (30 $\mathrm{cm}$. in diameter) contained infested clay soil by spore suspension of any of the five isolates of F. oxysporum $\left(1 \times 10^{3}\right.$ conidia / $\mathrm{ml}$ water) at the rate of $100 \mathrm{ml} /$ pot. Also, Three transplants were transplanted in each plastic pot $(30 \mathrm{~cm}$. in diameter) contained disinfested clay soil and served as control. Five pots were used for each treatment. The plants were left to grow under greenhouse conditions.

The pots were irrigated when it was necessary and fertilized with recommended doses as recommended by Min. of Agric. and Land Reclamation.

The plants were examined for the severity of infection by the tested fungus two months after transplanting as mentioned under disease assessment and the averages were recorded.

Also, plant height $(\mathrm{cm})$, fresh and dry weight of the foliage growth/ plant of the grown plants were estimated and recorded.

Eight tested plants, i.e. bean (Bronco cv.), cucumber (Admiral cv), eggplant (Balady white cv.), melon (Shahd Edfina cv.), sweet pepper (Balady cv.), strawberry (Camarosa $\mathrm{cv}$.), tomato (GS cv.) and watermelon (Giza $1 \mathrm{cv}$.) were grown in plastic pots infested or not with $F$. oxysporum isolate of Kalubia governorate and left two grow for two months, then incidence of Fusarium wilt was recorded.

\subsection{Isolation, Purification and Identification of the Bacterial Antagonists}

Soil samples collected from the rhizospheric soil of healthy eggplant plants grown in a field have severe infection by Fusarium wilt, were used to isolate the antagonists. Serial dilution plate technique was used to isolate native Bacillus spp. as well as Pseudomonas fluorescens and P. putida on nutrient agar medium [21]. The isolated bacteria were purified and identified using the description of [16], [23].

\subsection{Effect of the Culture Filtrate of Bacterial Bioagents on the Linear Growth and Germination of Conidiospores of the Causal Pathogen}

The effect of the culture filtrate of five isolates of Bacillus spp., i.e. Bacillus chitinosporus, B. megaterium, B. pumilus, $B$. subtilis and $B$. thuringiensis as well as $P$. fluorescens and $P$. putida on the linear growth and germination of conidiospores of $F$. $o$. f.sp. melongenae was studied. Hundred $\mathrm{ml}$. of nutrient medium were put in each $250 \mathrm{ml}$ flask and sterilized by steamer for three successive days. The medium 
was inoculated with two loops of the culture of any of the tested bioagents (taken from two days-old culture). Inoculated flasks were incubated on a rotary shaker at 200 rpm for 2 days at $30 \pm 2{ }^{\circ} \mathrm{C}$. The culture filtrate was filtered through Whitman No.1 filter paper and the filtrate was collected in a flask. Bacterial culture filtrate was sterilized using $0.25 \mu \mathrm{m}$ syringe filter. The culture filtrate of the bioagents was added to PDA medium just before solidifycation in different proportions $(20,30,40$ and $60 \%)$, shake well and poured into the Petri-dishes $(20 \mathrm{ml} / \mathrm{plate})$. After solidification the Petri-plates were inoculated with $5 \mathrm{~mm}$. discs of the test pathogen cut from the five days old culture. PDA plates inoculated with the test pathogen, but not amended with the culture filtrate of the tested bioagents, were maintained as control. Plates were then incubated in an incubator at $30 \pm 2^{\circ} \mathrm{C}$. Five replications were maintained for each treatment. The linear growth was measured when the plates of the control treatment covered with the fungal growth. Inhibition percentage of the mycelial growth of the tested pathogen was calculated by the following formula:

$$
\mathrm{I}=(\mathrm{C}-\mathrm{T}) / \mathrm{C} \mathrm{X} 100
$$

Where;

$\mathrm{I}=$ Percent of inhibition in growth of the tested pathogen,

$\mathrm{C}=$ Linear growth of the pathogen $(\mathrm{mm})$ in control,

$\mathrm{T}=$ Linear growth of the pathogen $(\mathrm{mm})$ in treatment.

Also, the prepared concentrations of the tested bioagents were added to the fungal growth in the Petri-dishes to make a conidial spore suspension for the causal fungus. One $\mathrm{m} 1$. of conidial suspension was placed on each sterilized slide, borne on two glass rods in a sterilized Petri-dish (two slides in each Petri-dish) containing a piece of wetted cotton by sterilized distilled water to provide high relative humidity. The same was made for a spore suspension put in distilled sterilized water only as control treatment. Preparations were incubated in darkness at $30 \pm 2^{\circ} \mathrm{C}$ for 24 hour. Five Petri dishes for each treatment were used as replicates. The percentages of conidial germination were counted in a total of 100 conidiospore in each glass slide. The germinated conidia were counted and the mean was calculated and recorded for each treatment.

\subsection{Effect of Filtrate of Compost Tea on the Linear Growth and Germination of Conidiospores of the Causal Fungus}

Compost (500 g.) was soaked in 2 liter tap water over night and filtered through Whitman filter paper No1. Compost tea was sterilized using $0.25 \mu \mathrm{m}$ syringe filter and added to PDA medium after sterilization at the concentrations of 20,30, 40 and $60 \%$, shake well and poured into the Petri-dishes $(20 \mathrm{ml} /$ plate $)$. After solidification the Petri-plates were inoculated with $5 \mathrm{~mm}$. discs of the test pathogen cut from the five days old culture. PDA plates inoculated with the test pathogen, but not amended with the compost tea were maintained as control. Plates were then incubated in an incubator at $30 \pm 2^{\circ} \mathrm{C}$. Five replications were maintained for each treatment. The linear growth was measured when the plates of the control treatment covered with the fungal growth. Inhibition percentage of the mycelial growth of the tested pathogen was calculated as mentioned before.

The prepared concentrations of compost tea were added to the fungal growth in the Petri-dishes to make a conidial spore suspension for the causal fungus. One $\mathrm{ml}$. of conidial suspension was placed on each sterilized slide, borne on two glass rods in a sterilized Petri-dish (two slides in each Petridish) containing a piece of wetted cotton by sterilized distilled water to provide high relative humidity. The same was made for a spore suspension put in distilled sterilized water only as control treatment. Preparations were incubated in darkness at $30 \pm 2^{\circ} \mathrm{C}$ for 24 hour. Five Petri-dishes for each treatment were used as replicates. The percentages of conidial germination were counted in a total of 100 conidiospore in each glass slide. The germinated conidia were counted and the mean was calculated and recorded for each treatment.

\subsection{Effect of the Combination Among B. subtilis, $P$. fluorescens and Compost on Wilt Severity and Some Crop Parameters}

Plots $(1 \mathrm{x} 1 \mathrm{~m})$ containing formalin sterilized clay soil were infested with the conidial spore suspension of the causal pathogen ( 2 liter of $1 \times 10^{6}$ spore / liter water). The plots were divided into two groups; the first one contained formalin sterilized clay soil and the second group contained formalin sterilized clay soil amended with compost ( $2 \mathrm{~kg}$./plot). Each group received the following treatments:

1. The plots supplied with the growth suspension of $B$. subtilis at the rate of 2 liter cfu $\left(1 \times 10^{6} / \mathrm{ml}\right.$.) / plot, one week before transplanting..

2. The plots supplied with the growth suspension of $P$. fluorescens at the rate of 2 liter cfu $\left(1 \times 10^{6} / \mathrm{ml}\right.$. $) /$ plot, one week before transplanting..

3. The plots supplied with compost at the rate of $2 \mathrm{~kg}$. / plot, one week before transplanting.

4. The plots supplied with the growth suspension of $B$. subtilis the rate of 2 liter cfu $\left(1 \times 10^{6} / \mathrm{ml}\right.$. $) /$ plot plus compost at the rate of $2 \mathrm{~kg}$. / plot, one week before infestation with F.o. f.sp. melongenae (FOM) and transplanting.

5. The plots supplied with the growth suspension of $P$. fluorescens at the rate of 2 liter cfu $\left(1 \times 10^{6} / \mathrm{ml}\right.$. $) /$ plot plus compost at the rate of $2 \mathrm{~kg}$. / plot, one week before infestation with FOM and transplanting.

6. The plots supplied with one liter growth suspension from both $B$. subtilis and $P$. fluorescens, one week before infestation with FOM and transplanting.

7. The plots were left without any treatment to grow the plants, but received 2 liter water only (control uninfested soil).

8. The plots were left without supplying any additional from the bioagents, but infested with the spore suspension of the causal fungus at the rate of 2 liter 
spore suspension / plot, one week before transplanting.

9. The plots were infested with the spore suspension of the causal fungus at the rate of 2 liter / plot, one week before transplanting and 5 liters (one g/ liter water) from the fungicide Topsin M-70 (Thiophanate-methyl) were added as soil drench before transplanting.

Six transplants (Balady white cv.) of 30 day-old, grown in foam trays contained disinfested soil (peat moss + clay +sand+ vermiculite soil), were transplanted in each plot. Three plots were used for each treatment, disease severity, plant height $(\mathrm{cm})$, the number and weight of fruits / plant were assessed and recorded.

\subsection{Disease Assessment}

The severity of Fusarium wilt was assessed five months after transplanting using the devised scale ( 0 to 5$)$ by [4] on the foliage growth using the following scale:

Where:

$0=$ No foliar symptoms,

$1=$ Chlorosis and/or wilt restricted to the first leaf,

$2=$ Chlorosis and/or wilt extending beyond the first leaf,

3 = Moderate to severe foliar symptoms usually with some abscised leaves,

$4=$ Severe foliar symptoms on the entire plant, and

$5=$ Dead plant.

Disease severity on foliage growth $\%=£(n x v) / 5$ N X 100

Where:

$\mathrm{n}=$ Number of wilted leaves in each category.

$\mathrm{v}=$ Numerical values of each category.

$\mathrm{N}=$ Total number of the wilted leaves.

The plants were, also, rated for vascular discoloration by the causal fungus using the devised scale $(0-5)$ by [31] using the following formula:

Where:

$0=$ No discoloration,

$1=$ Light discoloration evident as spotty areas in the longitudinal-section of the basal stem and upper part of the root,

$2=$ More continuous discoloration covering an area between one quarter and one half of the basal stem and upper part of the root, but light in color,

3 = Vascular discoloration (moderate in color) evident in a band encircling almost the entire of the basal stem and upper part of the root,

4 = Vascular discoloration darker in color than in 1 or 2 , and evident across most of the vascular tissue in a the basal stem and upper part of the root, and

5 = Plant severely damaged, vascular discoloration evident throughout the basal stem and upper part of the root.

Disease severity on the vascular $\%=£(n x v) / 5$ N X 100

Where:

$\mathrm{n}=$ Number of infected vascular in each category.

$\mathrm{v}=$ Numerical values of each category.

$\mathrm{N}=$ Total number of the infected vascular.

Also, plant height $(\mathrm{cm})$ of the grown plants, the average No. of fruits / plant and weight of fruits (g) / plant were estimated and recorded.

\subsection{Estimation of Total Phenol Compounds}

One gram of eggplant leaf samples was extracted with 10 $\mathrm{ml}$ of $80 \%$ methanol at $70{ }^{\circ} \mathrm{C}$ for $15 \mathrm{~min}$. Reaction mixture was containing $1 \mathrm{ml}$ of methanol extracts, $5 \mathrm{ml}$ of distilled sterilized water, and $250 \mu \mathrm{l}$ of Folin-Ciocalteau reagent $(1 \mathrm{~N})$. This solution was kept at $25 \pm 1{ }^{\circ} \mathrm{C}$. The absorbance of the developed blue color was measured using a spectrophotometer at $725 \mathrm{~nm}$. Gallic acid was used as the standard. The amount of phenol compounds was expressed as $\mathrm{mg}$ gallic acid per $\mathrm{g}$ roots material [41]. The assessment was carried out 40 and 45 days after inoculation by the causal fungus(FOM).

\subsection{Statistical Analysis}

Data were statistically analyzed using the standard procedures for complete randomize block, split and split split designs as mentioned by [28]. The averages were compared at $5 \%$ level using least significant differences (L. S. D.) according to [12].

\section{Results}

\subsection{Isolation, Purification and Identification of the Associated Fungi to Eggplant Wilt}

Isolation trials from eggplant plants (Balady white cv.), showing characteristic symptoms of wilt disease, collected from Dakahlia, Menofia, Kalubia, Giza and Fauoum governorates yielded many fungal isolates. The isolated fungi were purified and identified as: Alternaria spp., Fusarium spp., F. oxysporum, F. solani, Macrophomina phaseolina, Pythium spp., Rhizontonia solani, Sclerotium rolfsii and Verticillium dahliae.

The isolates of the fungus $F$. oxysporum were selected and tested for their pathogenicity and the most virulent isolate was chosen.

\subsection{Pathogenicity Test of F. oxysporum Isolates and Identification of the Forma Specials}

The five $F$. oxysporum isolates (Table, 1) reveal that they were pathogenic to eggplant plants and showing typical wilt symptoms on the foliage growth and the xylem vesicles. Moreover, the isolate of Kalubia governorate was the highest virulent one on both the foliage growth $(48.2 \%)$ and the xylem vesicles $(53.0 \%)$ and resulted in the lowest values of plant height $(70.6 \mathrm{~cm})$, foliage fresh $(423.8 \mathrm{~g})$ and dray $(52.5 \mathrm{~g})$ weight compared with the other isolates. Meanwhile, Fayoum isolate resulted in the lowest figures of the disease, being 37.3 and $43.9 \%$ and the lowest effect in reducing plant height and foliage fresh and dry weight, being $81.1 \mathrm{~cm}, 469.3$ and $58.8 \mathrm{~g}$, respectively. The remained three isolates recorded intermediate values. No apparent symptoms of Fusarium wilt were observed on the control plants and showed good growth. Thus, Kalubia isolate was used in the 
following experiments.

Testing of bean (Bronco cv.), cucumber (Admiral cv.), eggplant (Balady white cv.), melon (Shahd Edfina cv.), sweet pepper (Balady cv.), strawberry (Camarosa cv.), tomato (GS $\mathrm{cv}$.) and water melon (Giza $1 \mathrm{cv}$.) to their susceptibility to the infection by $F$. oxysporum indicated that the highest infection by the fungus was occurred only on eggplant and low or no apparent infection were occurred in case of the other plants. Therefore, the fungus $F$. oxysporum named Fusarium oxysporum f.sp. melongenae (FOM).

Table 1. Pathogenicity test of five isolates of F. oxysporum using transplants of eggplant (Balady white cv.), greenhouse experiment.

\begin{tabular}{llllll}
\hline \multirow{2}{*}{ Isolates } & \multicolumn{2}{l}{ A Disease severity on } & \multicolumn{2}{l}{ Average of } \\
\cline { 2 - 6 } & Foliage growth & Xylem vesicles & Plant height $(\mathbf{c m})$ & Foliage fresh weight (g) & Foliage dry weight (g) \\
\hline Dakahlia & 38.0 & 45.4 & 79.2 & 460.2 & 57.2 \\
Menofia & 40.2 & 46.0 & 76.2 & 451.4 & 55.3 \\
Kalubia & 48.2 & 53.0 & 70.6 & 423.8 & 52.5 \\
Giza & 44.1 & 51.4 & 71.3 & 435.2 & 83.2 \\
Fayoum & 37.3 & 43.9 & 81.1 & 769.3 & 58.8 \\
Control & 0.0 & 0.0 & 98.0 & & 74.5 \\
\hline
\end{tabular}

\subsection{Effect of Culture Filtrate of Five Bacillus Strains as Well as two Pseudomonas Strains on the Linear Growth and the Germinated Conidiospores of the Causal Pathogen}

The bacterial bioagents, i.e. B. chitinosporus, $B$. megaterium, B.pumilus, B.subtilis, B. thuringiensis, Pseudomonas fluorescens and P.putida were isolated from the rihizosperic soil of the healthy eggplant roots (Table,2).

Data presented in Tables ( 2 and 3 ) show that all the tested bacterial bioagents resulted in significant reduction to the linear growth and the germinated conidiospores of the causal pathogen (FOM) compared with control treatment. This reduction was gradually increased by increasing the tested concentration.
Table 2. Effect of culture filtrate of five Bacillus strains and two Pseudomonas spp. on the linear growth of FOM, six days after incubation at $30 \pm 2^{\circ} \mathrm{C}$.

\begin{tabular}{llllll}
\hline \multirow{2}{*}{ Bioagents } & \multicolumn{5}{c}{ Average linear growth (mm) at concentration of (\%) } \\
\cline { 2 - 6 } & $\mathbf{2 0}$ & $\mathbf{3 0}$ & $\mathbf{4 0}$ & $\mathbf{6 0}$ & Mean \\
\hline B. chitinosporus & 80.4 & 41.2 & 23.2 & 0.0 & 36.2 \\
B. megaterium & 72.8 & 32.6 & 0.0 & 0.0 & 26.4 \\
B. pumilus & 76.4 & 37.2 & 22.5 & 0.0 & 34.0 \\
B. subtilis & 69.4 & 29.0 & 0.0 & 0.0 & 24.6 \\
B. thuringiensis & 71.8 & 30.2 & 0.0 & 0.0 & 25.5 \\
P. fluorescens & 70.0 & 29.6 & 0.0 & 0.0 & 19.9 \\
P. putida & 76.0 & 35.2 & 17.6 & 0.0 & 32.2 \\
Control & 90.0 & 90.0 & 90.0 & 90.0 & 90.0 \\
Mean & 75.9 & 40.6 & 19.2 & 11.3 & ----- \\
\hline
\end{tabular}

L. S. D. at $5 \%$ for:

Bioagents $(B)=2.7$, Concentration $(C)=3.4, B x C=4.6$.

Table 3. Effect of culture filtrate of five Bacillus strains and two Pseudomonas strains on the average percentage of the germinated conidiospores of FOM, 24 h. after incubation at $30 \pm 2^{\circ} \mathrm{C}$.

\begin{tabular}{|c|c|c|c|c|c|}
\hline \multirow{2}{*}{ Bioagents } & \multicolumn{5}{|c|}{ Average percentage of the germinated conidiospores $\left(. x 10^{3}\right)$ at concentration of $(\%)$} \\
\hline & 20 & 30 & 40 & 60 & Mean \\
\hline B. chitinosporus & 72.0 & 38.2 & 16.0 & 0.0 & 31.6 \\
\hline B. megaterium & 64.8 & 20.8 & 0.0 & 0.0 & 21.4 \\
\hline B. pumilus & 74.4 & 40.2 & 18.8 & 0.0 & 33.4 \\
\hline B. subtilis & 58.0 & 25.4 & 0.0 & 0.0 & 20.9 \\
\hline B. thuringiensis & 69.4 & 26.4 & 0.0 & 0.0 & 24.0 \\
\hline P. fluorescens & 56.4 & 24.0 & 0.0 & 0.0 & 20.1 \\
\hline P. putida & 71.8 & 36.2 & 15.4 & 0.0 & 30.9 \\
\hline Control & 95.0 & 95.0 & 95.0 & 95.0 & 95.0 \\
\hline Mean & 60.3 & 38.3 & 18.2 & 11.9 & ---- \\
\hline
\end{tabular}

L. S. D. at $5 \%$ : Bioagents $(B)=2.8$, Concentration $(C)=3.7, B \times C=4.2$.

Table (2) reveals that $P$. fluorescens was the most efficient one in reducing the linear growth of the causal pathogen, being $19.9 \mathrm{~mm}$., on the average followed by $B$. subtilis, being $24.6 \mathrm{~mm}$., on the average then $B$. pumilus, being $34.0 \mathrm{~mm}$., on the average and $B$. megaterium, being $26.4 \mathrm{~mm}$., on the average Meanwhile, $B$. chitinosporus was the lowest efficient one being, $36.2 \mathrm{~mm}$, on the average followed by $P$. putida, being $32.6 \mathrm{~mm}$., on the average.

The effect of culture filtrate of the tested Bacillus strains as well as $P$. fluorescens and $P$. putida on the germinated conidiospores of the causal pathogen was in the same trend of the effect on the linear growth of the causal pathogen (Table, 3). In this respect, the conidiospores of the causal pathogen failed to geminate at the concentration of $40 \%$ of the culture filtrate of $B$. megaterium, $B$. subtilis, $B$. thuringiensis and $P$. fluorescens and at the concentration of $60 \%$ for $B$. chitinosporus, B. pumilus and P. putida. 


\subsection{Effect of Compost Tea Filtrate on the Linear Growth and the Germinated Conidiospores of the Causal Pathogen}

Results shown in Table (4) show that the filtrate of the soaked compost (compost tea) caused significant reduction to the linear growth of $F$. $o$. f. sp. melongenae, six days after incubation at $30 \pm^{\circ} \mathrm{C}$ compared with control treatment This reduction was gradually increased by increasing the used concentration. In addition, the causal fungus failed to grow on the concentration of $60 \%$. Meanwhile, conidiospores failed to germinate at $40 \%$ concentration. However, control treatment recorded $90 \mathrm{~mm}$. linear growth and $92.4 \%$, on the average conidial germination.

Table 4. Effect of compost tea on the linear growth and the germinated conidiospores of FOM, 6 and 24 h. after incubation at $30 \pm 2^{\circ} \mathrm{C}$, respectively.

\begin{tabular}{lll}
\hline Concentration $(\%)$ & Linear growth $(\mathbf{m m})$ & \% Conidiospores germination $\left(\ldots \times 1 \mathbf{0}^{3}\right)$ \\
\hline 20 & 73.0 & 53.0 \\
30 & 43.6 & 35.6 \\
40 & 24.4 & 0.0 \\
60 & 0.0 & 0.0 \\
Control & 90.0 & 92.4 \\
L. S. D. at 5\% & 2.7 & 3.2 \\
\hline
\end{tabular}

\subsection{Effect of B. subtilis and P. fluorescens in Combination with Compost on the Severity of Eggplant Wilt as Well as Plant Height and the Produced Fruit Yield}

Data presented in Tables (5 and 6) show that the two tested bioagents each alone or in combination resulted in significant reduction to eggplant wilt with significant increase to plant height as well as the number of fruits and their weight/ plant compared with the control treatment (infested soil). In addition, no visual symptoms were observed due to infesting the soil with the tested two bioagents only as well as control plants (un-infested soil). However, soil amended with compost was suppressive to the disease either the two tested bioagents were added to the soil or not. The lowest disease severity was recorded when Topsin M-70 was added to the soil as soil drench, being $2.4 \%$. on the average. Meanwhile, when any of $B$. subtilis and $P$. fluorescens and both were added to the soil infested with the causal fungus 10.0, 8.1 and $4.1 \%$ disease severity, on the average were recorded, respectively. Plants grown in soil infested with the causal fungus only recorded $26.3 \%$ disease severity, on the average. The severity of the disease was, to somewhat, higher on the foliage growth than on the xylem vesicles (vascular), being 6.8 and $5.8 \%$, on the average, respectively. In addition, plants grown in soil infested with any of $B$. subtilis and $P$. fluorescens were of high values of plant height and fruit yield (number and weight / plant) than those grown in the control (un-infested soil). In addition, the efficiency of the two tested bioagents were more efficient in reducing the severity of the disease and increasing values of plant height and fruit yield (number and weight / plant) when the soil was amended with compost compared with un-amended soil with compost.

Table 5. Effect of B. subtilis, P. fluorescens and compost on the severity of eggplant wilt, greenhouse experiment.

\begin{tabular}{|c|c|c|c|c|c|c|c|}
\hline \multirow[b]{3}{*}{ Treatments } & \multicolumn{7}{|c|}{$\%$ Disease severity on } \\
\hline & \multicolumn{2}{|c|}{ Foliage growth } & \multicolumn{2}{|c|}{ Xylem vesicles } & \multicolumn{2}{|l|}{ Mean } & \multirow{2}{*}{$\begin{array}{l}\text { General } \\
\text { Mean }\end{array}$} \\
\hline & Clay soil & Clay soil & Clay soil & Clay soil & Clay soil & Clay soil & \\
\hline & & + & & + & & + & \\
\hline & only & compost & only & compost & only & compost & \\
\hline B. subtilis (BS) & 0.0 & 0.0 & 0.0 & 0.0 & 0.0 & 0.0 & 0.0 \\
\hline P. fluorescens (PF) & 0.0 & 0.0 & 0.0 & 0.0 & 0.0 & 0.0 & 0.0 \\
\hline $\mathrm{BS}+\mathrm{FOM}$ & 12.4 & 9.0 & 9.9 & 7.0 & 11.2 & 8.8 & 10.0 \\
\hline $\mathrm{PF}+\mathrm{FOM}$ & 10.6 & 7.2 & 8.4 & 6.2 & 9.5 & 6.7 & 8.1 \\
\hline $\mathrm{BS}+\mathrm{PF}+\mathrm{FOM}$ & 5.6 & 4.2 & 4.0 & 2.4 & 4.8 & 3.3 & 4.1 \\
\hline Topsin M-70+FOM & 2.8 & 1.7 & 3.9 & 1.0 & 3.3 & 1.4 & 2.4 \\
\hline Control (Un-infested) & 0.0 & 0.0 & 0.0 & 0.0 & 0.0 & 0.0 & 0.0 \\
\hline Control (infested) & 32.0 & 23.5 & 29.3 & 20.0 & 30.7 & 21.8 & 26.3 \\
\hline Mean & 7.9 & 5.7 & 6.9 & 4.6 & 7.4 & 5.3 & -- \\
\hline General mean & 6.8 & & 5.8 & & ------ & & ----- \\
\hline
\end{tabular}

LSD at $5 \%$ for: Treatments $(T)=2.5$, Site of the disease $(\mathrm{SD})=2.3$, Soil type $(\mathrm{ST})=1.9, \mathrm{~T} \times \mathrm{SD}=3.0, \mathrm{~T} \times \mathrm{ST}=1.9, \mathrm{SD} \times \mathrm{ST}=2.7$ and $\mathrm{T} \times \mathrm{SD} \times \mathrm{ST}=3.8$. 
Table 6. Effect of the bioagents B. subtilis and P. fluorescens as well as compost on plant height and the produced fruit yield / plant, greenhouse experiment.

\begin{tabular}{|c|c|c|c|c|c|c|}
\hline Treatments & Clay soil only & & & Clay soil + compos & & \\
\hline & Plant height $(\mathrm{cm})$ & No. of fruits /plant & $\begin{array}{l}\text { Weight of fruits } \\
\text { (g)/plant }\end{array}$ & Plant height (cm) & No. of fruits/plant & $\begin{array}{l}\text { Weight of fruits } \\
\text { (g)/plant }\end{array}$ \\
\hline B. subtilis (BS) & 83.3 & 21.3 & 978.0 & 91.5 & 25.0 & 1050.0 \\
\hline P. fluorescens (PF) & 84.5 & 22.0 & 989.8 & 92.0 & 25.0 & 1064.0 \\
\hline $\mathrm{BS}+\mathrm{FOM}$ & 75.0 & 16.7 & 745.9 & 78.0 & 18.3 & 890.0 \\
\hline $\mathrm{PF}+\mathrm{FOM}$ & 77.3 & 16.7 & 754.4 & 78.3 & 18.7 & 898.0 \\
\hline $\mathrm{BS}+\mathrm{PF}+\mathrm{FOM}$ & 80.3 & 18.0 & 895.0 & 86.4 & 21.7 & 947.1 \\
\hline Control (Un-infested & 82.9 & 20.0 & 963.0 & 90.0 & 24.0 & 1020.0 \\
\hline Control (infested) & 57.0 & 11.3 & 458.3 & 66.7 & 560.0 & 536.8 \\
\hline L. S. D. at $5 \%$ & 3.1 & 2.6 & 7.8 & 3.3 & 7.1 & 7.1 \\
\hline
\end{tabular}

\subsection{Effect of the Two Bacterial Bioagents, Compost and Pathogen Treatment on the Content of Eggplant Roots from Phenol Compounds}

Table (7) shows that the tested two bacterial bioagents and compost resulted in considerable increase in the phenol compounds contents in the roots of eggplant plants with low variation in their values compared with the two controls. In addition, compost was the most efficient one in this regard, being $0.65 \mathrm{mg} / \mathrm{g}$ plant fresh roots, on the average followed by $B$. subtilis and P. fluorescens, being 0.64 and $0.62 \mathrm{mg} / \mathrm{g}$ plant fresh roots, on the average, respectively. Meanwhile, the lowest value of the phenol content was found in the roots of the control (infested soil) followed by that found in the roots of the plants grown in un-infested soil by the causal pathogen, being 0.41 and $0.47 \mathrm{mg} / \mathrm{g}$ plant fresh roots, on the average, respectively.

Table 7. Effect of two bacteria bioagents, compost and pathogen treatment on the phenol compounds content of eggplant roots,30 and 45 days after inoculation with the causal pathogen.

\begin{tabular}{lllll}
\hline \multirow{2}{*}{ Treatments } & \multicolumn{2}{l}{$\begin{array}{l}\text { Gallic acid in } \mathbf{~ m g} / \mathbf{g} \text { fresh roots after } \\
\text { (days) }\end{array}$} & \multicolumn{3}{c}{ Mean } \\
\cline { 2 - 4 } & $\mathbf{0 . 0}$ & $\mathbf{3 0}$ & $\mathbf{4 5}$ & \\
\hline B. subtilis & 0.44 & 0.68 & 0.79 & 0.64 \\
P. fluorescens & 0.44 & 0.65 & 0.76 & 0.62 \\
Compost & 0.44 & 0.70 & 0.81 & 0.65 \\
Control (infested) & 0.44 & 0.41 & 0.38 & 0.41 \\
Control (Uninfested) & 0.44 & 0.46 & 0.50 & 0.47 \\
\hline
\end{tabular}

\section{Discussion}

The fungus Fusarium oxysporum f. sp. melongenae is the most destructive causal pathogen causing eggplant (Solanum melongena 1.) wilt. The fungus is a soil-borne pathogen that invades the vascular vesicles, causes severe wilting and dying the above ground parts of the plants by blocking the xylem transport vesicle (s). It is extremely difficult to manage soil-borne fungi by conventional methods. The application of bioagents is important, since they may increase beneficial microbial activity, which extends for a long period of time.

Plant growth-promoting rhizobacteria (PGPR) are beneficial bacteria found on plant roots and in compost that can induce disease resistance and growth promotion by a wide variety of mechanisms.

Isolation trials from eggplant plants (Balady white cv.), showing characteristic symptoms of wilt disease, collected from Dakahlia, Menofia, Kalubia, Giza and Fayoum governorates yielded many fungal isolates. The isolated fungi were purified and identified as: Alternaria spp., Fusarium spp., F. oxysporum, F. solani, Macrophomina phaseolina, Pythium spp., Rhizontonia solani, Sclerotium rolfsii and Verticillium dahliae. Pathogenicity test of the five isolate of F. oxysporum revealed that Kalubia isolate was the most virulent one. In addition, testing eight plant species, i.e. bean (Bronco cv.), cucumber (Admiral cv), egg-plant (Balady white cv.), melon (Shahd Edfina cv.), sweet pepper (Balady cv.), strawberry (Camarosa cv.), tomato (GS cv.) and watermelon (Giza $1 \mathrm{cv}$.) to their infection by $F$. oxysporum proved that it infected eggplant only causing wilt, therefore named Fusarium oxysporum f. sp. melongenae.

The bacterial bioagents, i.e. B. chitinosporus, $B$. megaterium, B.pumilus, B.subtilis, B. thuringiensis, $P$. fluorescens and P.putida were isolated from the rhizospheric soil of the healthy eggplant roots.

The tested bacterial bioagents resulted in significant reduction to the linear growth and the germinated conidiospores of the causal pathogen compared with control treatment. This reduction was gradually increased by increasing the tested concentration.

Compost tea caused significant reduction to the linear growth and the germinated conidiospores of the causal fungus. This reduction was, also, gradually increased by increasing the tested concentration. Similar results were obtained by [27].

It has been found that, both linear growth and the germinated conidia of the causal pathogen were completely inhibited by the culture filtrate of B. megaterium, B. subtilis, $B$. thuringiensis and $P$. fluorescens at the concentration of $40 \%$ and by the other bioagents, i.e. B. chitinosporus, $B$. pumilus and $P$. putida at the concentration of $60 \%$. Meanwhile, the linear growth of the causal pathogen was completely inhibited by compost tea at the concentration of $60 \%$ and the germinated conidia at the concentration of $40 \%$. In all cases, the conidiospores were more sensitive to the tested bioagents and compost tea than the mycelium of the pathogenic fungus.

The tested bioagents resulted in significant reduction to eggplant wilt with significant increase to the plant height as 
well as the number of fruits and their weight / plant when added to soil infested with the causal pathogen compared with infestation with the causal pathogen only. However, Topsin M-70 was the superior treatment in decreasing the severity of the disease and increasing plant height and the produced fruit yield. In addition, the two tested bioagents were more efficient in reducing the severity of the disease and increasing values of plant height and fruit yield number and weight / plant) when the soil was amended with compost compared with un-amended soil with compost. This may be due to compost comprises a substrate medium for the growth and reproduction of the two bioagents, hence increasing mode of action of two bioagents. The obtained are in the harmony with the reported results by [1], [2], [6]. [22]. [26], [30], [39] [40].

Colonization of plant roots by selected strains of nonpathogenic bacteria, such as various species of the genus Bacillus [19] can induce a distinct broad-spectrum resistance response in both below- and above-ground parts of the plant. This type of resistance to diseases is named as induced systemic resistance (ISR) [11], [32]. The fungus Fusarium oxysporum is one of soil-borne plant pathogens and is widely distributed in various soil types worldwide. Recently, there has been a growing interest in nonpathogenic bacteria due to their efficacy as bioagents in many crops [2], [3], [23], [30], [40]. Application of some Bacillus strains to the seedlings has been found to be effective for suppressing soil-borne diseases and has successfully induced systemic resistance in the treated plants [19], [29]. Elicitation of ISR by Bacillus strains has been demonstrated in greenhouse or field trials on tomato, bell pepper, muskmelon, watermelon, sugar beet, tobacco, Arabidopsis sp., cucumber, loblolly pine, and two tropical crops [19], [29].

Bacillus spp. grow very fast and occupies the court of infection and preventing pathogen spores to reach susceptible tissues in competition for spaces [36]. This might be due to that treatments with biopreparation induce systemic resistance as the main mechanism of activity on the plant. Also, [39] reported that B. subtilis CAS15 has great potential for plant growth promotion and biological control, where reduced the incidence of Fusarium wilt in pepper significantly, by $12.5-56.9 \%$ due to induced systemic resistance. They added that there were significant increases in plant height also enhanced the yield of pepper by shortening the time to 50 percent flowering to 17.26 days, increasing the average fruit weight $36.92 \%$, and increasing the average yield per plant $49.68 \%$. This research showed that B. subtilis CAS15 has great potential for plant growth promotion and biological control.

It is supposed that Bacillus spp. could be have diverse plant response involved in synthesis and accumulation of antimicrobial phytoalexins [14], [18], induction of hypersensitive response [15], production of defense-related proteins [38] production of activated oxygen species [8] and modification of plant cell wall by deposition of callose [34].

Protection of plants from disease by induction of systemic resistance is a new approach. This is much less harmful to the environment as compared to deadly agrochemicals applied to control plant diseases.

The bioactivity of $P$. fluorescens might be due to produces different types of antibiotics including active 2, 4 diacetylphloroglucinole (2, 4 DAPB), which control diseases and/or due to that $P$. fluorescens has several methods to control the disease such as production of antifungal compounds including siderophre production, nutrient competition and the induction of systemic resistance [25]. Also, [20] reported that the reduction in the infection by plant pathogens and the increase in the plant length and fresh weight of the treated plants might be due to $P$. fluorescens produces of indole acetic acid as a growth regulator as well as some antibiotic, i.e. pyrrolnitrin, pyoluterin and 2, 4 diacetyl phloroglucino.

Compost is considered one of the different available sustainable approaches that may be used to prevent, mitigate or to control plant diseases. Organic amendments play an important role as environmentally friendly and sustainable alternative approach to protect plants against soil borne pathogens. Soil amendments, using composted agricultural wastes fortified with biocontrol agents could be acceptable approaches in this regard. The use of organic agricultural wastes in this respect can be an advantageous both in soil fertility, recycling of agricultural residues and could provide a powerful tool for management of plant diseases. It has been reported that several composts and/or composts fortified with bioagent used as soil amendments reduced pathogens propgules density and protected plants from soil-borne plant pathogens [17], [37]. Therefore, although disease control effectiveness by compost can be variable [30], the economic and environmental benefits deriving from its use can win any form of distrust that could hover on operators. In addition, it is supposed that compost may be acts as a nutrient source and shelter for the bioagents that compete with plant pathogens, for those organisms that prey on and parasitize pathogens, and for those beneficial that produce antibiotics.

It has been found that $B$. subtilis, $P$. fluorescens and compost resulted in considerable higher production of phenol compounds without great variation in their values compared with control treatment and soil infested with F.o. f.sp. melongenae. A great increase was observed in the total phenol compounds of plants treated with compost followed by the two tested bioagents..

Phenol compounds content are compounds whose quantity raised when a plant comes under attack by a pathogen [33], [35]. Systemic induction of phenol compounds under influence of bacterial strains was first reported by [33]. However, this alone is not reliable for indication of disease resistance in plant tissues [35]. [3] reported that a significant increase in total phenol contents was observed in bacterialtreated plants. They added that pathogen alone was able to induce phenol formation in plants but with slightly increased levels. Similar results were obtained [1], [35].

\section{Conclusion}

Biological control is considered an important approach of 
agricultural biotechnology in recent years for controlling many soil-borne plant pathogens, which considers an environmentally friendly and sustainable alternative approach for disease management. The obtained results give a potential of the combination of $B$. subtilis and $P$. fluorescens with compost as efficient protection agents against Fusarium wilt of eggplant.

\section{References}

[1] Abada, K. A. and Ahmed, M. A. (2014). Management Fusarium wilt of sweet pepper by Bacillus strains. The Amer. J. of Life Sci., 2 (3): 11-18.

[2] Abada, K. A. and Hassan, Eman O. (2017). Effect the combination among compost, bioagents and soil solarizaton on management of strawberry Verticillium wilt. Inter. J. of Sci. \& Eng. Res., 8 (2) 88-99.

[3] Akram, W.; Mahboob, A. and Javel, A. A. (2013). Bacillus thuringiensis strain 199 can induce systemic resistance in tomato against Fusarium wilt. Eur. J. of Mirobiol. and Immunol., 275-280.

[4] Amini, J. and Sidovich, D. F. (2010). The effects of fungicides on Fusarium oxysporum f. sp. lycopersici associated with Fusarium wilt of tomato. J. of Plant Protec. Res., 50 (2), $175-$ 180.

[5] Altinnok, H. H. (2005). First report of Fusarium wilt of eggplant caused by Fusarium oxysporum f. sp. melongenae in Turkey. Plant Pathology, 54: 577.

[6] Altinok, H. H.; Dikilitas, M. and Yildiz, H. N. (2013). Potential of Pseudomonas and Bacillus Isolates as biocontrol agents against Fusarium wilt of eggplant. Biotechnology and Biotechnological Equipment, 27:4, 3952-3958.

[7] Albersheim, P. and Valent, B. S. (1978). Host-pathogen interactions in plants. Plants, when exposed to oligosaccharides of fungal origin, defend themselves by accumulating antibiotics. J. Cell Biol., 78 (3):627-643.

[8] Baker, C. J.; Orlandi, E. W. and Mock, N. M. (1993). Harpin, an elicitor of the hypersensitive response in tobacco caused by Erwinia amylovora, elicits active oxygen production in suspension cells. Plant Physiol., 102 (4):1341-1344.

[9] Brewer, M. T. and Larkin, R. P. (2005). Efficacy of several potential biocontrol organisms against Rhizoctonia solani on potato. Crop Protec., 24: 939-950.

[10] Booth, C. (1971). The genus Fusarium. Commonwealth Mycological Institute, Kew, Surrey, England.

[11] de Vleesschauwer, D. and Hofte, M.. (2009). Rhizobacteriainduced systemic resistance. Adv. Bot. Res.,; 51:223-281.

[12] Fisher, R. A., (1948). Statistical Methods $6^{\text {th }}$ ed. Iowa State Univ. Press, Ames, Iowa, USA.

[13] Gilman, J. C. (1957). A Manual of Soil Fungi. The Iowa State College Press, Iowa, USA. 450 pp.

[14] Hammond-Kosack K. E. and Jones, J. D. (1996). Resistance gene-dependent plant defense responses. Plant Cell, 8 (10):1773-1791.
[15] He, S. Y.; Huang, H. C. and Collmer, A. (1993). Pseudomonas syringae pv. syringae harpin Pss: a protein that is secreted via the Hrp pathway and elicits the hypersensitive response in plants. Cell., 73 (7):1255-1266.

[16] Holt, J. G. and Krieg, N. R (1984). Bergey's Manual of Systematic Bacteriology. Williams \& Wilkins, Baltimore, USA.

[17] Khalil, I. and El-Mghrabia, K. (2010). Biological control of Fusarium dry rot and other potato tuber diseases using Pseudomonanas fluorescens and Enterobacter cloacae. Biological Control, 53 (3): 280-284.

[18] Jacobsen, B. J.; Zidack, N. K. and Larson, B. J. 2004. The role of Bacillus-based biological control agents in integrated pest management systems: Plant diseases. Phytopathology, 94:1272-1275.

[19] Kloepper, J. W.; Ryu, C. M. Zhang, S. (2004). Induced systemic resistance and promotion of plant growth by Bacillus spp. Phytopathology, 94 (11):1259-1266.

[20] Meena, B.; Marimuthu, T. and Velazhahan, R. (2006). Role of fluoroscent pseudomonas in plant growth promotion and biological control of late leaf spot of groundnut. Acta Phythopathologica et Entomologica Hungarica, 41 (3-4): 203212.

[21] Oedjijono, M. A. L. and Dragar, C. (1993). Isolation of bacteria antagonistic to a range of plant pathogenic fungi. Soil Biol. Biochemis., 25: 247-250.

[22] Patil, V. M.; Patole, K. R.; Paprikar, M. S. and Rajput, J. C. (2017). Biological control of brinjal wilt caused by Fusarium oxysporum f. sp. melongenae using soluble powder formulation of Aspergillus niger. Int. J. Adv. Res. Biol. Sci., 4 (11): 66-71.

[23] Parry, J. M.; Turnbull, P. C. B. and Gibson, J. R. (1983). A colour atlas of Bacillus species, Wolfe Medical Publications Ltd.

[24] Ragab, Mona M. M.; Abada, K. A.; Abd-El-Moneim, Maisa L. and, Abo-Shosha Yosra Z. (2015). Effect of different mixtures of some bioagents and Rhizobium phaseoli on bean damping-off under field condition. Inter. J. of Sci. and Eng. Res., 6 (7):1009-1106.

[25] Ramamoorthy, V.; Viswanathan, R.; Raguchander, T.; Pkakasam, V. and Samivappan, R. (2001). Induction of systemic resistance by plant growth promoting rhizobacteria in crop plants against pests and diseases. Crop Protec., 20 (1): 1-11.

[26] Safikhani, N.; Morid, B. and Zamanizadeh, H. R. (2013). First report of Fusarium wilt of eggplant caused by Fusarium oxysporum f. sp. melongenae in Iran. New Disease Reports, 28: 16.

[27] Said, E.; El-Hassan, A.; Abdellatif, H.; jamal, I.; Saadia, B.; Fouad, R.; Ghizlane, E. and Rachid, B. (2017). In vitro evaluation of compost extracts efficiency as biocontrol agent of date palm Fusarium wilt. Afr. J. Microbiol. Res., 11 (29):1155-1161.

[28] Snedecor, G. W. and Cochran, W. G. (1967). Statistical Methods. $6^{\text {th }}$ Ed. Iowa State. Univ. Press, Ames, Iowa, USA.

[29] Szczech, M. and Shoda, M. (2006). The effect of mode of application of Bacillus subtilis RB14-C on its efficacy as a biocontrol agent against Rhizoctonia solani. J. Phytopathol., $154: 370-377$. 
[30] Termorshuizen, A. J.; van Rijn, E.; van der Gaag, D. J.; Alabouvette, C.; Chen, Y.; Lagerlöf, J.; Malandrakis, A. A.; Paplomatas, E. J.; Rämert, B.; Ryckeboer, J.; Steinberg, C. and Zmora-Nahum. S (2007). Suppressiveness of 18 composts against 7 pathosystems: variability in pathogen response. Soil Biol. Biochemis., 38:2461-2477.

[31] Ulloa, M..; Hutmacher R. B.; Davis R. M..; Wright S. D.; Percy R., and Marsh B. (2006). Breeding for Fusarium wilt race 4 resistance in cotton under field and greenhouse conditions. The J. of Cotton Sci., 10:114-127.

[32] van Loon L. C. (2007). Plant responses to plant growthpromoting rhizobacteria. Eur. J. Plant Pathol., 119:243-254.

[33] van Peer, R.; Niemann, G. N. and Schippers, B. (1991). Induced resistance and phytoalexin accumulation in biological control of Fusarium wilt in carnation by Pseudomonas sp. strain WCS417r. Phytopathology, 81: 728-734.

[34] Veit S.; Wörle J. M.; Nürnberger T.; Koch W. and Seitz H. U. (2001). A novel protein elicitor (PaNie) from Pythium aphanidermatum induces multiple defense responses in carrot, Arabidopsis, and tobacco. Plant Physiol., 127 (3):832-841.

[35] Waterman, P. G. and Mole, S. (1995). Analysis of Phenolic Plant Metabolites. London: Blackwell Sci. Publ., Method in Ecology.
[36] Xing, L.; Ding, Z.; Wenxiang, Y.; Li, D. and Daqun, L. (2003). A study on the effect of Bacillus on downy mildew of cucumber. Plant Protec., 29 (4): 25-27.

[37] Yogen, A.; Raviv, M.; Hadar, Y.; Cohen, R. and Katan, J. (2006). Plant waste based composts suppressive to diseases caused by pathogenic Fusarium oxysporum. Eur. J. Plant Pathol., 116:267-276.

[38] Yu, L. M. (1995). Elicitins from Phytophthora and basic resistance in tobacco. Proc. Natl. Acad. Sci. U S A., 92 (10): 4088-4094.

[39] Yu, X.; Ai, C.; Xin L. and Zhou, G. (2011). The siderophoreproducing bacterium, Bacillus subtilis CAS15, has a biocontrol effect on Fusarium wilt and promotes the growth of pepper. Eur. J. Soil Biol., 47 (2):138-145.

[40] Zaher, Effat A.,; Abada, K. A. and Zyton, Marwa, A. (2013). Effect of combination between bioagents and solarization on management of crown-and stem-rot of Egyptian clover. Amr. J. of Plant Sci., 1 (3):43 -50.

[41] Zieslin, N. and Ben-Zaken. R. (1993). Peroxidase activity and presence of phenolic substances in peduncles of rose flowers. Plant Physiol. Biochemis., 31:333-339. 